\title{
Influence of sudden salinity variation on the physiology and domoic acid production by two strains of Pseudo-nitzschia australis
}

\author{
Ayache Nour ${ }^{1,}{ }^{*}$, Hervé Fabienne ${ }^{1}$, Martin-Jézéquel Veronique ${ }^{2}$, Amzil Zouher $^{1}$, Caruana Amandine ${ }^{1}$ \\ 1 IFREMER; Phycotoxins Laboratory; rue de l'lle d'Yeu, BP 2110544311 Nantes France \\ ${ }^{2}$ CNRS; UMR 7266; LIENSs, La Rochelle University; 2 rue Olympe de Gouges 17000 La Rochelle \\ France \\ * Corresponding author : Nour Ayache, email address : $\underline{\text { nour.ayache@ifremer.fr }}$
}

\begin{abstract}
:
Several coastal countries including France have experienced serious and increasing problems related to Pseudo-nitzschia toxic blooms. These toxic blooms occur in estuarine and coastal waters potentially subject to fluctuations in salinity. In this study, we document for the first time the viability, growth, photosynthetic efficiency and toxin production of two strains of Pseudo-nitzschia australis grown under conditions with sudden salinity changes. Following salinity variation, the two strains survived over a restricted salinity range of 30 to 35 , with favorable physiological responses, as the growth, effective quantum yield and toxin content were high compared to the other conditions. In addition, high cellular quotas of domoic acid (DA) were observed at a salinity of 40 for the strain IFR-PAU-16.1 in comparison with the other strain IFR-PAU-16.2 where the cell DA content was directly released into the medium. On the other hand, the osmotic stress imposed at lower salinities, 20 and 10, resulted in cell lysis and a sudden DA leakage in the medium. Intra-specific variability was observed in growth and toxin production, with the strain IFR-PAU-16.1 apparently able to withstand higher salinities than the strain IFR-PAU-16.2. On the whole, DA does not appear to act as an osmolyte in response to sudden salinity changes. Since most of the shellfish harvesting areas of bivalve molluscs in France are located in areas where the salinity generally varies between 30 and 35, Pseudo-nitzschia australis blooms might potentially impact public health and commercial shellfish resources in these places.
\end{abstract}

Keywords: Amnesic shellfish poisoning, domoic acid, harmful algae, Pseudo-nitzschia australis, salinity stress 


\section{Abbreviations}

API 4000 Trap, triple quadrupole mass spectrometer; ASP, amnesic shellfish poisoning; DA, domoic acid; dDA, dissolved domoic acid; $\mathrm{F}_{\mathrm{v}} / \mathrm{F}_{\mathrm{m}}$, effective quantum yield,; LOQ, Limit of quantification; LOD, Limit of detection; QY, quantum yield; UFLC, ultra-fast liquid chromatography

\section{Introduction}

The genus Pseudo-nitzschia is distributed throughout the world. At least 52 species are currently described of which 26 are known to produce a neurotoxin called domoic acid (DA; Ajani et al. 2018, Gai et al. 2018, Lundholm 2018). The consumption of DA-contaminated shellfish at concentrations higher than the EU-regulatory limit of $20 \mathrm{mg} \mathrm{DA} \cdot \mathrm{kg}^{-1}$, can cause severe amnesic shellfish poisoning (ASP; Visciano et al. 2016). The human illness associated with DA intoxication is characterized by gastrointestinal symptoms like nausea, cramps, vomiting and diarrhoea followed by neurological symptoms including severe headache, seizures, short term memory loss, coma and in severe cases, death (Lefebvre and Robertson 2010, La Barre et al. 2014, Tasker 2016). In addition to public health impacts, mortality events of marine birds and mammals linked to DA in the food web are also a serious ethical and economic issues (Beltrán et al. 1997, Gulland 2000, Pulido 2008). In recent decades, several species of toxic Pseudo-nitzschia, including $P$. australis, have been repeatedly reported along French coastlines (Amzil et al. 2001, Nezan et al. 2006, Husson et al. 2016) as well as in many other parts of the world such as the North and South Americas (Anderson et al. 2006, Bargu et al. 2008, Mather et al. 2010), other parts of Europe (Lundholm et al. 2006, Churro et al. 2009, Zapata et al. 2011, Orive et al. 2013), Asia and Africa (Hallegraeff 2004, Hasle and Lundholm 2005, Teng et al. 2016, Louw et al. 2018). Moreover, the species $P$. 
australis is considered one of the most toxic species worldwide (Thessen et al. 2009, Trainer et al. 2012). It was identified for the first time in France in 2004 as the main source of DA contamination in king scallops (Pecten maximus; Nezan et al. 2006, Amzil et al. 2007, Klein et al. 2010). Toxic blooms of Pseudo-nitzschia species appear to be increasing in frequency and toxicity (Trainer et al. 2009). Several studies have examined the environmental factors that may affect toxin production in Pseudo-nitzschia, such as $\mathrm{pH}$, salinity, temperature, irradiance, nutrient availability (silicate, phosphate, nitrate, and iron) and the presence of bacteria and copepod grazers (Pan et al. 1998, Cusack et al. 2002, Howard et al. 2007, Lelong et al. 2012, Tatters et al. 2012, Haroardóttir et al. 2015, Tammilehto et al. 2015). In addition, DA production may vary according to the inter- and intra-specific diversity commonly highlighted for the Pseudo-nitzschia genus, along with several physiological factors such as the age of the culture and the growth phase (lag, exponential and stationary phases). This highlights the difficulties in predicting the initiation of Pseudo-nitzschia blooms and DA production in the environment (Lundholm et al. 1997, Bates and Trainer 2006, Lelong et al. 2012, Kim et al. 2015, Godhe and Rynearson 2017).

Most of the Pseudo-nitzschia species are euryhaline (i.e., able to grow in a wide range of salinities, and can inhabit coastal areas exposed to significant and long lasting changes in sea water salinity; Jackson et al. 1992, Lundholm et al. 1997, Bates 1998, Thessen et al. 2005). The increase in frequency of storm tides, rise in water temperatures, altered precipitation and run-off can all cause the salinity level of coastal aquatic and estuarial ecosystems to change, and major alterations might be expected in phytoplankton diversity, dominance and toxin production (Stocker et al. 2013). According to several studies on climate change, salinity alterations have already been observed and are predicted to intensify worldwide (IPCC 2007). The consequences of such changes in water salinity may have an impact on the frequency, intensity and the duration of Pseudo-nitzschia blooms and their 
ability to produce toxins (Hallegraeff 2010, Wells et al. 2015, Van Meerssche and Pinckney 2017). To our knowledge, very few studies have been conducted on the effect of salinity variation on growth and DA production by other Pseudo-nitzschia species (P. multiseries, $P$. delicatissima, P.pungens, P. calliantha), and those studies that were carried out tested only one acclimated strain as a representative of the studied species (Lundholm et al. 1997, Thessen et al. 2005, Doucette et al. 2008, Van Meerssche and Pinckney 2017, Pednekar et al. 2018). During cell growth in hypersaline conditions, diatoms can establish cellular adaptation mechanisms in order to compensate the osmotic pressure (Schobert 1974). The osmotic balance can be achieved by ion accumulation mechanisms (sodium uptake) or by the synthesis and accumulation of osmolytes, which are low-molecular weight organic solutes (Liu and Hellebust 1976, Schobert 1977, Masmoudi et al. 2013). In diatoms, osmolytes are commonly amino acids like proline, lysine, taurine, alanine, arginine, glutamic acid and aspartic acid (Fujii et al. 1995). However, while Doucette et al. (2008) and Pednekar et al. (2018) noticed an increase in DA production with increasing salinity in $P$. multiseries and $P$. pungens cells, the potential physiological role of DA as an osmolyte have not yet been fully confirmed (Doucette et al. 2008, Lelong et al. 2012, Pednekar et al. 2018).

According to an FAO survey, France is the top shellfish producer in the EU, with an estimated production of 187,420 tons in 2002 for a turnover of 371 million euros (Food and Agricultural Organization FAO 2005). The present article reports for the first time, the effect of salinity shock on two strains of $P$. australis isolated from French waters and grown in batch cultures. The two studied strains were subjected to five different salinity conditions (10, $20,30,35$ and 40$)$ and their growth, effective quantum yield $\left(\mathrm{F}_{\mathrm{v}} / \mathrm{F}_{\mathrm{m}}\right)$ and toxin production were measured following the salinity shock. The aim of this study is to better understand the physiology of these toxic Pseudo-nitzschia strains, the possible role of DA as an osmolyte in the cells and to test whether the toxicity of Pseudo-nitzschia cells might be dependent on 
salinity. The overall objective is to investigate the effect of instantaneous salinity changes on P. australis cells and their ability to produce toxin. The acquired knowledge will be made available to help predict potential $P$. australis toxic blooms and their economic and health impacts on shellfish resources and local communities.

Materials and methods

Culture conditions

Two strains of Pseudo-nitzschia australis were used in this study, strains IFR-PAU-16.1 and IFR-PAU-16.2, which were isolated in May 2016 from the Bay of Arcachon, located on the south-western Atlantic coast of France $\left(44^{\circ} 40^{\prime} \mathrm{N}, 1^{\circ} 10^{\prime} \mathrm{W}\right)$. Both strains were confirmed to produce domoic acid. The cultures were grown in $1 \mathrm{~L}$ polystyrene culture flasks containing sterile L1 medium (Guillard and Hargraves 1993). Natural seawater was filter-sterilized through a $0.22 \mu \mathrm{m}$ polycarbonate membrane filter (Corning, NY, USA) and enriched with L1 media with additional silicate for a final concentration of $100 \mu \mathrm{M}$ as described by Guillard and Hargraves (1993). The P. australis strains were grown in batch cultures and routinely maintained in a temperature-controlled room at $16^{\circ} \mathrm{C}$, exposed to a photon flux density of 120 $\mu \mathrm{mol}$ photons $\cdot \mathrm{m}^{-2} \cdot \mathrm{s}^{-1}$ (fluora and cool-white fluorescent light, Osram, Germany) in a 12 : $12 \mathrm{~h}$ light:dark cycle. Natural seawater obtained from the English Channel, with a salinity of 35, was selected as a control medium for comparison of salinity-induced stress. The natural seawater was diluted with distilled water to reach the salinities 10, 20 and 30. To provide a salinity treatment of 40 , seawater was freeze-concentrated.

This article is protected by copyright. All rights reserved. 


\section{Experimental set-up}

Pseudo-nitzschia australis strains IFR-PAU-16.1 and IFR-PAU-16.2 were cultured for one week in L1 growth medium at salinity 35 (i.e., the same salinity that was subsequently used as a control condition in the experiment). The cells were then centrifuged for $5 \mathrm{~min}$ at $150 \mathrm{~g}$ and $25^{\circ} \mathrm{C}$ and transferred into new culture media of different salinities $(10,20,30,35$ and 40). Initial inocula concentrations for strains IFR-PAU-16.1 and IFR-PAU-16.2 before centrifugation were $17 \times 10^{3}$ cells $\cdot \mathrm{mL}^{-1}$ and $16 \times 10^{3}$ cells $\cdot \mathrm{mL}^{-1}$, respectively. Triplicate cultures of each salinity condition were incubated in $1 \mathrm{~L}$ polystyrene bottles (Nest Biotechnology, China) at $16^{\circ} \mathrm{C}$, with $120 \mu \mathrm{mol}$ photons $\cdot \mathrm{m}^{-2} \cdot \mathrm{s}^{-1}$ photon flux density and 12:12 h light - dark cycle. Monitoring was carried out $4 \mathrm{~h}$ after the salinity shock $\left(\mathrm{T}_{0}\right)$, than daily for $4 \mathrm{~d}\left(\mathrm{~T}_{1}, \mathrm{~T}_{2}, \mathrm{~T}_{3}\right.$ and $\left.\mathrm{T}_{4}\right)$ at a fixed time corresponding to the middle of the light cycle. Percentage cell mortality was calculated with data collected four $\mathrm{h}$ after the transfer of cultures to the different salinities. Calculation was based on the differences between cell counts of the control culture at salinity 35 and those at the different salinities $(10,20,30,35$ and 40).

\section{Physiological measurements}

A daily sampling of $35 \mathrm{~mL}$ of each culture was used in order to measure cell growth, effective quantum yield (QY) $\mathrm{F}_{\mathrm{v}} / \mathrm{F}_{\mathrm{m}}$, and DA content. Growth was monitored by daily cell counts of Lugol fixed samples (1\% final concentration). A minimum of 400 viable cells were counted using a Nageotte counting chamber with a light microscope (Leica Microsystems Switzerland) at 10x magnification. When growth occurred, the specific growth rate for the mean value of the triplicate cultures $\left(\mu \cdot \mathrm{d}^{-1}\right)$ was calculated for the period of the first three 
days. When the strains did not grow, negative growth rates were calculated one day after the salinity stress according to the equation given in by Guillard (1973):

$\mu=\left(\ln \mathrm{N}_{1}-\ln \mathrm{N}_{3}\right) /\left(\mathrm{T}_{1}-\mathrm{T}_{3}\right)$

where $\mathrm{N}$ is cell density at a given time $(\mathrm{T})$.

A PhytoPAM Phytoplankton fluorometer (Walz, Effeltrich, Germany) was used for the measurements of the effective quantum yield $(\mathrm{QY})$ of the primary photosystem PSII $\left(\mathrm{F}_{\mathrm{v}} / \mathrm{F}_{\mathrm{m}}\right)$. For each culture, $\mathrm{F}_{\mathrm{v}} / \mathrm{F}_{\mathrm{m}}$ was calculated via an assessment of the chlorophyll fluorescence yield and the saturation pulse using the following equation (Schreiber et al. 2002):

$\mathrm{QY}=\left(\mathrm{F}_{\mathrm{m}}-\mathrm{F}_{0}\right) / \mathrm{F}_{\mathrm{m}}$

where $\mathrm{F}_{0}$ is the minimum fluorescence measured after a period of complete darkness, $\mathrm{F}_{\mathrm{m}}$ is the maximum fluorescence obtained during a saturating light pulse when all reaction centers are closed, and $\mathrm{F}_{\mathrm{v}}=\mathrm{F}_{\mathrm{m}}-\mathrm{F}_{0}$.

\section{Toxin analyses}

In order to determine the toxin content (particulate and dissolved in the medium) of the two Pseudo-nitzschia australis strains in different salinity treatments, $15 \mathrm{~mL}$ of culture were centrifuged $\left(5 \mathrm{~min}, 3600 \mathrm{~g}, 4^{\circ} \mathrm{C}\right)$ and separated into cell pellet and filtrate. DA concentrations in the particulate fraction were determined by extraction of the cell pellet in $1 \mathrm{~mL}$ methanol/water mixture (50/50: v/v) and stored at $-80^{\circ} \mathrm{C}$. Before analysis, the extraction was prolonged by 15 min of sonication in an ice-cold bath then centrifuged and filtered (15 min, $\left.8000 \mathrm{~g}, 4^{\circ} \mathrm{C}, 0.2 \mu \mathrm{m}\right)$ to recover the supernatant (Amzil et al. 2007). 
DA content in the dissolved fraction was extracted by solid phase extraction (SPE) using Agilent Bond Elut C18 200 mg cartridges. The SPE column was conditioned with 10 $\mathrm{mL}$ methanol followed by $10 \mathrm{~mL}$ of ultra-pure water. The sample was then passed through the SPE column after acidifying with $20 \%$ aqueous formic acid to give $0.2 \%$ formic acid. The cartridge was rinsed with $10 \mathrm{~mL}$ of $0.2 \%$ aqueous formic acid then dried for 1 minute. DA, adsorbed on the cartridge, was eluted with $1.5 \mathrm{~mL}$ of methanol/water $(50 / 50 \mathrm{v} / \mathrm{v})$ into a glass vial and stored at $-80^{\circ} \mathrm{C}$ for later analysis.

DA analyses were performed using Ultra-Fast Liquid Chromatography (UFLC, Shimadzu) coupled to an ABSciex API 4000QTrap triple quadrupole mass spectrometer. The chromatographic separation was carried out on a Kinetex C18 column $(150 \times 2.1 \mathrm{~mm}, 2.6$ $\mu \mathrm{m}$, Phenomenex) equipped with a pre-column. Certified DA standard (CNRC, Halifax, Canada) was used for external calibration range in order to quantify DA in sea water. LOD and LOQ are respectively 0.1 and $0.25 \mathrm{ng} \cdot \mathrm{mL}^{-1}$.

\section{Statistical analyses}

The experiment was carried out in triplicate and the data presented are mean standard deviation (SD) for $n=3$. Statistical analyses were performed to determine whether the growth, effective quantum yield $\left(\mathrm{F}_{\mathrm{v}} / \mathrm{F}_{\mathrm{m}}\right)$, or the DA content of the two tested strains significantly varied $(\mathrm{p}<0.05)$ for the different salinity conditions. Data were analysed statistically using nonparametric Kruskal-Wallis tests followed by multiple comparison tests ( $\mathrm{H}$ tests) to determine the source of significant differences. All comparisons were made against the salinity 35 control data and analyses were performed using R software version 3.4.1, 2017.

This article is protected by copyright. All rights reserved. 
Results

Cell growth, effective quantum yield and domoic acid content (particulate, dissolved and total domoic acid) of the two strains of IFR-PAU-16.1 and IFR-PAU-16.2 were all influenced by the sudden changes in salinity conditions (Figs. 1-4).

The salinity stress led to an instantaneous decrease in cell density for all cultures, with a percentage of mortality ranging from $18 \%$ to $93 \%$ (Fig. 1). At salinities 20 and 10, the two strains showed a sharp increase in mortality ( $84 \%$ to $93 \%$ cell mortality), while small increases were observed at salinities 40 and 30 (18\% to $38 \%$ cell mortality; see Table S1 in the Supporting Information, Fig. 1). Similarly, control cultures, at 35 salinity, showed a moderate cell mortality of $20 \%$ and $18 \%$ for strains IFR-PAU-16.1 and IFR-PAU-16.2, respectively (Table S1, Fig. 1). This was likely due to culture centrifugation and transfer to new media at the beginning of the experiment. At salinity 30, the two strains IFR-PAU-16.1 and IFR-PAU-16.2 showed high growth rates of $0.39 \cdot \mathrm{d}^{-1}$ and $0.43 \cdot \mathrm{d}^{-1}$, respectively. Moderately lower growth rates of $0.35 \cdot \mathrm{d}^{-1}$ and $0.19 \cdot \mathrm{d}^{-1}$ were observed at salinity 35 for strains IFR-PAU-16.1 and IFR-PAU-16.2, respectively. However, at salinities 10, 20 and 40, neither strain showed any growth at all (Figs. 1,2), and negative growth rates were observed (e.g.,- $-0.29 \cdot \mathrm{d}^{-1},-0.39 \cdot \mathrm{d}^{-1}$, and $-0.04 \cdot \mathrm{d}^{-1}$, respectively) in IFR-PAU-16.2 . After the salinity shock, growth recovery was observed at salinity 30 during the four days of culture, and a slight and progressive decrease in cell density was observed at salinity 40 (Fig. 2). In transfers to salinities 10 and 20, the osmotic shock led to cell lysis and very low cell densities. The highest cell concentrations were reached on days 3 and 4 for both strains at salinities $30\left(26 \times 10^{3}\right.$ and $21 \times 10^{3}$ cells $\left.\cdot \mathrm{mL}^{-1}\right)$ and $35\left(26 \times 10^{3}\right.$ and $20 \times 10^{3}$ cells $\cdot \mathrm{mL}^{-1}$; Fig. 2).

This article is protected by copyright. All rights reserved. 
The salinity shocks of 20 and 10 for the two Pseudo-nitzschia strains also had a negative effect on the cellular photosynthetic efficiency (Fig. 3). The effective quantum yield $F_{v} / F_{m}$ of the stock culture was 0.65 for both strains (Fig. 3). Following the salinity stress treatments, the $\mathrm{F}_{\mathrm{v}} / \mathrm{F}_{\mathrm{m}}$ values declined in both strains, possibly as a consequence of the cell transfer process. However, cultures transferred at salinities 40, 35 and 30 showed a recovery of the effective quantum yield, as the $\mathrm{F}_{\mathrm{v}} / \mathrm{F}_{\mathrm{m}}$ value remained stable throughout the growth period (Fig. 3). The $\mathrm{F}_{\mathrm{v}} / \mathrm{F}_{\mathrm{m}}$ of cultures at salinity 40 decreased on the last two days of the experiment to minima of 0.47 and 0.38 for IFR-PAU-16.1 and IFR-PAU-16.2, respectively. The $\mathrm{F}_{\mathrm{v}} / \mathrm{F}_{\mathrm{m}}$ yield was greatest for cultures at salinity 30 with values equal to 0.67 for IFRPAU-16.1 and IFR-PAU-16.2, and similar for cultures at 35 salinity ( 0.65 for both strains; Fig. 3). However, cultures subjected to salinity stress of 20 underwent a drop in the $F_{v} / F_{m}$ just after the transfer (0.11 and 0.09 for IFR-PAU-16.1 and IFR-PAU-16.2, respectively), whereas at salinity 10 , photosynthetic efficiency was reduced to almost nothing $(0.01$ and 0.02 , respectively).

The initial particulate domoic acid content of all cultures was $0.25 \mathrm{pg} \cdot$ cell $^{-1}$ and 0.16 $\mathrm{pg} \cdot \mathrm{cell}^{-1}$ for IFR-PAU-16.1 and IFR-PAU-16.2, respectively. Neither strain survived the osmotic shock when subjected to salinity stress at 10 or 20 as this resulted in cell lysis (Fig. 2). Cell lysis effects were also observable on the dissolved DA concentration (Fig. 4, C and D), as high amounts of dissolved DA were detected in the culture medium from the beginning of the experiment and remained constant over the four next days (almost $3 \mathrm{ng} \cdot \mathrm{mL}^{-1}$ for IFRPAU-16.1 and IFR-PAU-16.2 at salinities 10 and 20). This shows that the entire DA cell content had been released into the culture medium. At salinity 40, particulate DA showed a slow and steady increase for IFR-PAU-16.1 ( $0.24 \mathrm{pg} \cdot$ cell $^{-1}$ at day 4) and very low levels of particulate DA for IFR-PAU-16.2 (0.03 pg · cell $^{-1}$ at day 4; Fig. 4, A and B). In addition, the highest total DA content (particulate and dissolved) differed substantially between the two 
lowest salinities and other salinities tested. At salinities 30, 35 and 40, high amounts of DA were detected after the salinity shock. The highest total DA concentrations were reached in cultures at salinity 35 for strain IFR-PAU-16.1 $\left(13.8 \mathrm{ng} \cdot \mathrm{mL}^{-1}\right)$ and at salinity 30 for IFRPAU-16.2 $\left(15.2 \mathrm{ng} \cdot \mathrm{mL}^{-1}\right)$. An increase was observed during the two first days, which corresponds to the early exponential growth phase (Fig. S1 in the Supporting Information, Fig. 4, E and F). This was followed by a phase where DA production slowed down and stabilized at days 3 and 4, corresponding to the late exponential and stationary growth phases (Fig. S1). A slow and steady increase in DA was observed for strain IFR-PAU-16.1 at salinities 30 and 40, and for IFR-PAU-16.2 at salinities 35 and 40 (Fig. 4, E and F). The large increase of total DA observed at the beginning of the experiment for salinities 35 and 30 resulted from the accumulation of DA inside the cell during the first day for IFR-PAU-16.1 (from 0.19 to $0.46 \mathrm{pg} \cdot$ cell $^{-1}$ for salinity 35 ) and the two first $\mathrm{d}$ for IFR-PAU-16.2 (from 0.10 to $0.78 \mathrm{pg} \cdot$ cell $^{-1}$ for salinity 30 ; Fig. 4 , A and B). This was followed by the decrease of intracellular DA content until the end of the experiment due to toxin release into the culture medium (Fig. 4, C and D). Dissolved DA showed a rapid and progressive increase after the medium change for the salinities 30,35 and 40 and reached elevated levels once cell concentrations reached a plateau. Dissolved DA reached its highest levels at salinity 35 for strain IFR-PAU-16.1 (7.8 ng $\left.\cdot \mathrm{mL}^{-1}\right)$ and 30 for strain IFR-PAU-16.2 (7.4 ng $\cdot \mathrm{mL}^{-1}$; Fig. 4, C and D). The concentration of dissolved DA in the medium was also high at salinity 40 for strain IFR-PAU-16.1 $\left(5.1 \mathrm{ng} \cdot \mathrm{mL}^{-1}\right)$. In contrast, the dissolved DA value for strain IFR-PAU16.2 at salinity 40 remained steady and low $\left(1.3 \mathrm{ng} \cdot \mathrm{mL}^{-1}\right.$ at day 4$)$ throughout the experiment (Fig. 4, C and D).

This article is protected by copyright. All rights reserved. 


\section{Discussion}

This study was the first investigation into the effects of salinity stress on two strains of the diatom Pseudo-nitzschia australis, considered to be one of the main species responsible for amnesic shellfish poisoning incidents worldwide (Bates 2000, Campbell et al. 2001, Husson et al. 2016). As reported in several studies, the expected future increases in salinity fluctuations in coastal and estuarine areas, brought about by climate change and anthropogenic pressure, could potentially affect the frequency and intensity of Pseudonitzschia blooms (IPCC 2007, McCabe et al. 2016). Our results indicate that such salinity fluctuations may also affect domoic acid (DA) production by Pseudo-nitzschia cells. Pseudonitzschia australis blooms have been reported every year in spring and autumn in many estuarine and coastal waters in France and other parts of the world (Hallegraeff 2004, Hasle and Lundholm 2005, Nezan et al. 2006, Husson et al. 2016). In particular, our experiments raise concern about the potential effects of rapid fluctuations of sea surface salinity as a result of rainfall or river discharge into the coastal areas and the effect of salinity increase during drought periods on cell viability and domoic acid content of $P$. australis cells. The results of this experiment clearly demonstrate that the studied strains can resist sudden salinity change over only a small range, here from 35 to 30 .

Previous field and laboratory studies on other Pseudo-nitzschia species ( $P$. multiseries, $P$. pungens, $P$. calliantha, $P$. cuspidata, and $P$. fraudulenta) have also reported impacts of salinity variation on growth and DA production (Lundholm et al. 1997, Thessen et al. 2005, Doucette et al. 2008, Thessen and Stoecker 2008, Markina and Aizdaicher 2016, Van Meerssche and Pinckney 2017, Pednekar et al. 2018). The results of these previous studies showed that high cell abundances and growth rates of Pseudo-nitzschia cells were associated with high salinity levels. A recent field study by Van Meerssche and Pinckney (2017) showed a positive correlation between dissolved DA concentrations and salinity. Their 
findings showed an increase in Pseudo-nitzschia abundance with increasing salinity but with less DA release in the water. Our results are in agreement with the laboratory studies on $P$. multiseries and P. pungens strains acclimated to different salinities (Doucette et al. 2008, Pednekar et al. 2018). Doucette et al. (2008) concluded that the P. multiseries strain was able to maintain high growth rates and its greatest cellular DA concentrations at higher salinities (three- to seven-fold higher total DA concentrations at salinities 30 and 40 compared with salinities 10 and 20). Additionally, a recent study by Pednekar et al. (2018) showed that the highest growth rates were obtained at salinities of 15 to 25 , and that higher and lower salinities resulted in a reduction of growth rate. This salinity range also corresponded to the area where this species was isolated and is commonly present in the Zuari and Mandovi estuaries in western India (Pednekar et al. 2018). The authors also found that DA production increased as salinity increased with the most produced at salinity 35 . However, the lack of laboratory studies on the effect of sudden salinity changes on toxic Pseudo-nitzschia species makes comparisons of our finding difficult, especially knowing the wide variability within and between Pseudo-nitzschia species (Casteleyn et al. 2010, Moschandreou et al. 2012, Tesson et al. 2014).

In comparison to previous studies examining $P$. australis growth rates with different nitrogen sources, the growth rates observed in our study at salinities 35 and 30 (0.39 and 0.43 $\cdot \mathrm{d}^{-1}$ respectively) were similar to those observed by Martin-Jézéquel et al. (2015; 0.33 to 0.60 $\left.\cdot \mathrm{d}^{-1}\right)$, and lower than those in Howard et al. $\left(2007 ; 0.52\right.$ to $\left.0.93 \cdot \mathrm{d}^{-1}\right)$. In addition, the cells maintained high effective quantum yield $\left(\mathrm{F}_{\mathrm{v}} / \mathrm{F}_{\mathrm{m}}\right)$. However, cultures at salinity 40 showed a slow decrease in $\mathrm{F}_{\mathrm{v}} / \mathrm{F}_{\mathrm{m}}$ while the biomass was rapidly decreasing suggesting that the effect of salinity stress was greater on cell division than on the effective quantum yield. Furthermore, in response to salinity stress at 10 and 20 , the effective quantum yield $\left(\mathrm{F}_{\mathrm{v}} / \mathrm{F}_{\mathrm{m}}\right)$ decreased severely, suggesting that the salinity drop to 10 and 20 was too excessive to allow the 
maintenance and protection of the cell membrane and caused direct cell lysis. These responses are common in plants and microalgae under severe environmental stress (Pancha et al. 2015, Chokshi et al. 2017).

Likewise, salinity stress also had an impact on toxin production of particulate and dissolved DA. High amounts of dissolved DA were detected four hours after cultures were transferred from salinity 35 to salinities 10 and 20 due to cell lysis (lysed cells were observed under the microscope). The DA content of these cultures remained stable until the end of the experiment, while for salinities 30, 35 and 40, a progressive release of DA was observed over the four days of the experiment (Fig. 4, C and D). The highest cell particulate DA contents detected for strains IFR-PAU-16.1 and IFR-PAU-16.2 $\left(0.46 \mathrm{pg} \cdot \mathrm{cell}^{-1}\right.$ and $0.76 \mathrm{pg} \cdot \mathrm{cell}^{-1}$, respectively) were lower than the values previously reported for $P$. australis strains studied by Buck et al. (Buck et al. 1992; 3 to $31 \mathrm{pg} \cdot$ cell $^{-1}$ ) and Trainer et al. (2000; 0.1 to $78 \mathrm{pg}$. cell $\left.^{-1}\right)$ and comparable to those measured by Campbell et al. $\left(2001 ; 1.2\right.$ to $\left.1.32 \mathrm{pg} \cdot \mathrm{cell}^{-1}\right)$, Cusack et al. (2002; 0.21 to $0.98 \mathrm{pg} \cdot$ cell $\left.^{-1}\right)$ and Rhodes et al. $\left(2002 ; 2 \mathrm{pg} \cdot\right.$ cell $\left.^{-1}\right)$. The particulate DA content measured in $P$. australis strains by Martin-Jézéquel et al. $(2015 ; 10.8$ to $30.3 \mathrm{fg} \cdot$ cell $\left.^{-1}\right)$ and Howard et al. $\left(2007 ; 0.48 \mathrm{fg} \cdot\right.$ cell $\left.^{-1}\right)$, however, were much lower than the detected concentrations in our experiment. Furthermore, the highest cellular DA contents were observed in the cultures at salinities 35 and 30, where growth rates and the effective quantum yield were high. In suitable growth conditions, the DA content of $P$. australis seemed to appear in two stages: a first one where the DA content (particulate) is greater than the release (dissolved), (until days 1 and 2 for both strains) and a second where the release in the culture medium prevails. Similar patterns of DA production in $P$. australis strains have also been reported in previous studies (Garrison et al. 1992, Howard et al. 2007, MartinJézéquel et al. 2015), where the highest cell DA contents were measured during the exponential or late-exponential growth phases. It was suggested that during active growth 
(exponential growth phase) in which no nutrients were limiting and the effective quantum yield $\left(\mathrm{F}_{\mathrm{v}} / \mathrm{F}_{\mathrm{m}}\right)$ was elevated, a large amount of metabolic energy was generated to fulfil the requirements of both growth and DA biosynthesis (Bates 1998, Maldonado et al. 2002). It is noteworthy that the majority of previous studies (Pan et al. 1996, Bates 1998, Doucette et al. 2008, Martin-Jézéquel et al. 2015) usually reported enhanced cellular DA levels during the mid-stationary growth phase in P. multiseries strains, and it has been speculated that the reduction or cessation of cell division during this phase could allow the cells to accumulate a higher particulate DA content, especially when nutrients (i.e., silicate and phosphate) are depleted in the medium. This variability in toxin production phase may be attributable to the wide interspecific diversity of Pseudo-nitzschia genus as well as changes in cell physiology (cell size, age of the culture) or their initial environmental conditions (Bates and Trainer 2006, Thessen et al. 2009, Moschandreou et al. 2012, Trainer et al. 2012, Gai et al. 2018). This exacerbates the difficulties of comparing different studies and deriving conclusions about the behavior observed.

The stress imposed by raising the salinity up to 40 induced the accumulation of high amounts of particulate DA in the strain IFR-PAU-16.1, while for the strain IFR-PAU-16.2, a much lower particulate DA content were observed, associated with a rapid increase of DA in the medium. These results suggest that IFR-PAU-16.1 had higher salinity tolerance (salinity 30 to 40 ) than IFR-PAU-16.2 (30 to 35) in terms of toxin production. Likewise, previous laboratory experiments conducted by Parkhill and Cembella (1999) on the marine dinoflagellate Alexandrium tamarense also showed that the sudden transfer of cells from salinity 30 into medium of 10 and 15 reduced toxin production, and caused an instantaneous leakage of toxins from the cells. Guerrini et al. (2007) found that the amount of yessotoxin released into the medium by the dinoflagellate Protoceratium reticulatum decreased as 
salinity increased, the highest amounts of cellular toxin was produced at intermediate salinity, with decreases at both lower and higher salinity levels.

Following a fluctuation in salinity, diatoms have been shown capable of producing and accumulating organic osmolytes in order to maintain cellular osmotic balance (Masmoudi et al. 2013). For example, Schobert (1974) reported high levels of proline in Cyclotella meneghiniana subjected to high salt concentrations. The levels of proline and lysine in Nitzschia ovalis were likewise found to increase as salinity went up (Garza-Sánchez et al. 2009). A study by Jackson et al. (1992) reported an increase in glutamic acid and taurine production in Pseudo-nitzschia pungens and $P$. multiseries following an increase in salinity conditions. Given that DA is highly structurally similar to common osmolytes in diatoms, like glutamic acid and aspartic acid (Lefebvre and Robertson 2010), it is tempting to suggest that DA acts as an osmolyte in response to increasing salinity as put forward by Bates (1998). In addition, Doucette et al. (2008), Van Meerssche and Pinckney (2017) and Pednekar et al. (2018) showed an increase in DA production with rising salinity levels, reinforcing the hypothesis of Bates (1998). In our study, the concentration of any osmolyte would be expected to decrease in cells transferred to lower salinity and to increase in cells transferred to higher salinity. Whereas a decrease in particulate DA was observed for strain IFR-PAU-16.1 when the salinity was decreased to 30, and a slow increase was found when cells were transferred to salinity 40. Particulate DA content remained lower at salinity 40 than at salinity 35. Likewise, higher particulate DA content were observed at salinity 30 than at salinities 35 for the strain IFR-PAU-16.2. When strain IFR-PAU-16.2 was grown at salinity 40, it produced lower amounts of DA that were directly released into the culture medium (no accumulation observed), probably because the salinity stress was too severe for this strain and damaged the cells. Therefore, with regard to abrupt salinity changes, DA does not seem to act as an osmolyte in $P$. australis cells in either of the two strains studied here. 
Furthermore, intra-specific variability was observed, as strain IFR-PAU-16.1 seemed to withstand higher salinities than strain IFR-PAU-16.2 in terms of growth capacities and DA content, with an optimal salinity at 35 , whereas this was 30 for IFR-PAU-16.2. The two strains of $P$. australis tested withstand and tolerate fluctuation in the salinity range 30 to 35 , in which cells continued to proliferate and produce high amounts of DA. As these salinities generally correspond to the areas along the French coast most heavily harvested areas for bivalve molluscs, ASP could be expected in these places. However, the osmotic stress imposed at salinities 20 and 10 resulted in cell lysis, inhibition of toxin biosynthesis and an immediate DA leakage into the medium. Thus, further investigations on the effect of salinity variation, done in acclimation mode rather than with a shock, would provide interesting complementary knowledge on the potential response of $P$. australis cell physiology, particularly regarding DA production in an environment of variable salinity.

\section{Conclusion}

In recent decades, 26 toxic Pseudo-nitzschia species have been reported in the world's oceans (Amzil et al. 2001, Trainer et al. 2009, Gai et al. 2018). These habitats are widely used as shellfish growing and harvesting areas and are often subjected to large fluctuations in salinity. These variations in salinity are influenced by various natural and/or anthropogenic environmental factors (heavy rain, river discharge, high evaporation). The results of our study revealed that the two studied strains show similar behaviour in response to sudden salinity variations, with a limited range of salinity tolerance between 30 and 35, and an intra-specific variability in term of optimal growth and DA content. Our result does not support the hypothesis of DA acting as an osmolyte in Pseudo-nitzschia australis cells subjected to rapid salinity change. Moreover, deviation from optimal salinities towards lower and higher levels (salinity 20 and 40) can stress cells, leading potentially to cell lysis, reduced growth, photosynthetic efficiency, and effects on DA production and release. These results indicates 
that $P$. australis is a salinity-sensitive species that will not thrive in coastal areas after large salinity fluctuations. It would now be useful to perform further laboratory studies on the impact of salinity variation on cell physiology and DA production mechanisms in acclimation mode.

\section{Acknowledgments}

The authors acknowledge Ifremer and the Regional Council of the Région des Pays de la Loire for the PhD funding of Nour Ayache. The authors would like to thank Elizabeth Nézan and Nicolas Chomérat from Ifremer, Concarneau, France for providing and identifying the Pseudo-nitzschia australis strains. 


\section{References}

Ajani, P.A., Verma, A., Lassudrie, M., Doblin, M.A. \& Murray, S.A. 2018. A new diatom species $P$. hallegraeffii sp. nov. belonging to the toxic genus Pseudo-nitzschia (Bacillariophyceae) from the East Australian Current. PLoS ONE 13:e0195622.

Amzil, Z., Fresnel, J., Le Gal, D. \& Billard, C. 2001. Domoic acid accumulation in French shellfish in relation to toxic species of Pseudo-nitzschia multiseries and $P$. pseudodelicatissima. Toxicon 39:1245-51.

Amzil, Z., Royer, F., Sibat, M., Fiant, L., Gelin, M., Le Gal, D. \& Françoise, S. 2007. First report on amnesic and diarrhetic toxins detection in French scallops during 2004-05 monitoring surveys. In Proceedings of the Sixth International Conference on Molluscan Shellfish Safety, Blenheim, Marlborough, New Zealand, pp. 307-14.

Anderson, C.R., Brzezinski, M.A., Washburn, L. \& Kudela, R. 2006. Circulation and environmental conditions during a toxigenic Pseudo-nitzschia australis bloom in the Santa Barbara Channel, California. Mar. Ecol. Prog. Ser. 327:119-33.

Bargu, S., Powell, C.L., Wang, Z., Doucette, G.J. \& Silver, M.W. 2008. Note on the occurrence of Pseudo-nitzschia australis and domoic acid in squid from Monterey Bay, CA (USA). Harmful Algae 7:45-51.

Bates, S.S. 1998. Ecophysiology and metabolism of ASP Toxin production. In Anderson, D. M., Cembella, A. D. \& Hallegraeff, G. M. [Eds.] Physiological Ecology of Harmful Algal Blooms. Springer-Verlag, Berlin, Germany, pp. 405-426.

Bates, S.S. 2000. Domoic-acid producing diatoms: another genus added. J. Phycol. 36:97883.

This article is protected by copyright. All rights reserved. 
Bates, S.S. \& Trainer, V.L. 2006. The Ecology of Harmful Diatoms. In Graneli, E. \& Turne, J. T. [Eds.] Ecology of Harmful Algae. Springer Berlin Heidelberg, Germany, pp. 81-93.

Beltrán, A.S., Palafox-Uribe, M., Grajales-Montiel, J., Cruz-Villacorta, A. \& Ochoa, J.L. 1997. Sea bird mortality at Cabo San Lucas, Mexico: Evidence that toxic diatom blooms are spreading. Toxicon 35:447-53.

Buck, K.R., Uttal-Cookel, L., Pilskaln, C.H., Roelke, D.L., Villac, M.C., Fryxell, G.A., Cifuentes, L. \& Chavez, F.P. 1992. Autecology of the diatom Pseudonitzschia australis, a domoic acid producer, from Monterey Bay, California. Mar. Ecol. Ser. 84:293-302.

Campbell, D.A., Kelly, M.S., Busman, M., Bolch, C.J., Wiggins, E., Moeller, P.D.R., Morton, S.L., Hess, P. \& Shumway, S.E. 2001. Amnesic shellfish poisoning in the king scallop, Pecten maximus, from the west cost of Scotland. J. Shellfish Res. 20:75-84.

Casteleyn, G., Leliaert, F., Backeljau, T., Debeer, A.-E., Kotaki, Y., Rhodes, L., Lundholm, N. , Sabbe, K. \& Vyverman, W. 2010. Limits to gene flow in a cosmopolitan marine planktonic diatom. Proc. Natl. Acad. Sci. USA 107:12952-7.

Chokshi, K., Pancha, I., Ghosh, A. \& Mishra, S. 2017. Salinity induced oxidative stress alters the physiological responses and improves the biofuel potential of green microalgae Acutodesmus dimorphus. Bioresour. Technol. 244:1376-83.

Churro, C.I., Carreira, C.C., Rodrigues, F.J., Craveiro, S.C., Calado, A.J., Casteleyn, G. \& Lundholm, N. 2009. Diversity and abundance of potentially toxic Pseudo-nitzschia peragallo in aveiro coastal lagoon, portugal and description of a new variety, $P$. pungens var. aveirensis var. nov. Diatom Res. 24:35-62.

Cusack, C.K., Bates, S.S., Quilliam, M.A., Patching, J.W. \& Raine, R. 2002. Confirmation of domoic acid production by Pseudo-nitzschia australis (Bacillariophyceae) isolated from 
Irish waters. J. Phycol. 38:1106-12.

Doucette, G.J., King, K.L., Thessen, A.E. \& Dortch, Q. 2008. The effect of salinity on domoic acid production by the diatom Pseudo-nitzschia multiseries. Nov. Hedwigia $133: 31$.

FAO 2005. Profil de la pêche par pays: la république française.

Fujii, S., Nishimoto, N., Notoya, A. \& Hellebust, J.A. 1995. Growth and osmoregulation of Chaetoceros muelleri in relation to salinity. Plant Cell Physiol. 36:759-64.

Gai, F.F., Hedemand, C.K., Louw, D.C., Grobler, K., Krock, B., Moestrup, Ø. \& Lundholm, N. 2018. Morphological, molecular and toxigenic characteristics of Namibian Pseudonitzschia species - including Pseudo-nitzschia bucculenta sp. nov. Harmful Algae 76:80-95.

Garrison, D.L., Conrad, S.M., Eilers, P.P. \& Waldron, E.M. 1992. Confirmation of domoic acid production by Pseudonitzschia australis (Bacillariophyceae) cultures. J. Phycol. 28:604-7.

Garza-Sánchez, F., Chapman, D.J. \& Cooper, J.B. 2009. Nitzschia ovalis (Bacillariophyceae) Mono Lake strain accumulates 1,4/2,5 cyclohexanetetrol in response to increased salinity. J. Phycol. 45:395-403.

Godhe, A. \& Rynearson, T. 2017. The role of intraspecific variation in the ecological and evolutionary success of diatoms in changing environments. Philos. Trans. R. Soc. B. 372:20160399.

Guerrini, F., Ciminiello, P., Dell'Aversano, C., Tartaglione, L., Fattorusso, E., Boni, L. \& Pistocchi, R. 2007. Influence of temperature, salinity and nutrient limitation on 
yessotoxin production and release by the dinoflagellate Protoceratium reticulatum in batch-cultures. Harmful Algae 6:707-17.

Guillard, R.R.L. 1973. Division rates. In Stein, J. [Ed.]. Handbook of phycological methods: culture methods and growth measurments.Cambridge University Press, New York, USA, pp. 289-312.

Guillard, R.R.L. \& Hargraves, P.E. 1993. Stichochrysis immobilis is a diatom, not a chrysophyte. Phycologia 32:234-6.

Gulland, F. 2000. Domoic acid toxicity in California sea lions (Zalophus californianus) stranded along the Central California Coast, May-October 1998. Report to the National Marine Fisheries service working group on unusual marine mammal mortality events.

Hallegraeff, G.M. 2004. Harmful algal blooms: a global overview. In Manual on Harmful Marine Microalgae. pp. 25-50.

Hallegraeff, G.M. 2010. Ocean climate change, phytoplankton community responses, and harmful algal blooms: A formidable predictive challenge. J. Phycol. 46:220-35.

Haroardóttir, S., Pančić, M., Tammilehto, A., Krock, B., Møller, E.F., Nielsen, T.G. \& Lundholm, N. 2015. Dangerous relations in the arctic marine food web: Interactions between toxin producing Pseudo-nitzschia diatoms and Calanus copepodites. Mar. Drugs. 13:3809-35.

Hasle, G.R. \& Lundholm, N. 2005. Pseudo-nitzschia seriata f. obtusa (Bacillariophyceae) raised in rank based on morphological, phylogenetic and distributional data. Phycologia $44: 608-19$.

Howard, M.D.A., Cochlan, W.P., Ladizinsky, N. \& Kudela, R.M. 2007. Nitrogenous

This article is protected by copyright. All rights reserved. 
preference of toxigenic Pseudo-nitzschia australis (Bacillariophyceae) from field and laboratory experiments. Harmful Algae 6:206-17.

Husson, B., Hernández-Fariñas, T., Le Gendre, R., Schapira, M. \& Chapelle, A. 2016. Two decades of Pseudo-nitzschia spp. blooms and king scallop (Pecten maximus) contamination by domoic acid along the French Atlantic and English Channel coasts: Seasonal dynamics, spatial heterogeneity and interannual variability. Harmful Algae 51:26-39.

IPCC 2007. Climate Change 2007: The Physical Science Basis. In Solomon, S., Qin, D. M., Manning, Z., Chen, M., Marquis, K. B., Averyt Tingor, M. \& Miller, H. L. [Eds.] Contribution of Working Group I to the Fourth Assessment Report of the Intergovernmental Panel on Climate Change. Cambridge University Press, Cambridge, New York, NY, USA, p. 996.

Jackson, A.E., Ayer, S.W. \& Laycock, M. V. 1992. The effect of salinity on growth and amino acid composition in the marine diatom Nitzschia pungens. Can. J. Bot. 70:2198201.

Kim, J.H., Park, B.S., Kim, J. H., Wang, P. \& Han, M. S. 2015. Intraspecific diversity and distribution of the cosmopolitan species Pseudo-nitzschia pungens (Bacillariophyceae): morphology, genetics, and ecophysiology of the three clades. J. Phycol. 51:159-72.

Klein, C., Claquin, P., Bouchart, V., Le Roy, B. \& Véron, B. 2010. Dynamics of Pseudonitzschia spp. and domoic acid production in a macrotidal ecosystem of the Eastern English Channel (Normandy, France). Harmful Algae 9:218-26.

La Barre, S., Bates, S.S. \& Quilliam, M.A. 2014. Domoic acid. In La Barre, S. \& Kornprobst, J. M. [Eds.] Outstanding Marine Molecules: Chemistry, Biology, Analysis. Wiley-VCH. 
KgaA, Weinheim, Germany, pp. 189-216.

Lefebvre, K.A. \& Robertson, A. 2010. Domoic acid and human exposure risks: A review. Toxicon 56:218-30.

Lelong, A., Hégaret, H., Soudant, P. \& Bates, S.S. 2012. Pseudo-nitzschia (Bacillariophyceae) species, domoic acid and amnesic shellfish poisoning: revisiting previous paradigms. Phycologia 51:168-216.

Liu, M.S. \& Hellebust, J.A. 1976. Effects of salinity and osmolarity of the medium on amino acid metabolism in Cyclotella cryptica. Can. J. Bot. 54:938-48.

Louw, D.C., Doucette, G.J. \& Lundholm, N. 2018. Morphology and toxicity of Pseudonitzschia species in the northern Benguela Upwelling System. Harmful Algae 75:11828.

Lundholm, N. 2018. Bacillariophyceae, in IOC-UNESCO Taxonomic Reference List of Harmful Micro Algae. Available At: http://www.marinespecies.org/hab.

Lundholm, N., Moestrup, Ø., Kotaki, Y., Hoef-Emden, K., Scholin, C. \& Miller, P. 2006. Inter- and intraspecific variation of the Pseudo-nitzschia delicatissima complex (Bacillariophyceae) illustrated by rRNA probes, morphological data and phylogenetic analyses. J. Phycol. 42:464-81.

Lundholm, N., Skov, J., Pocklington, R. \& Moestrup, Ø. 1997. Studies on the marine planktonic diatom Pseudo-nitzschia. 2. Autecology of P. pseudodelicatissima based on isolates from Danish coastal waters. Phycologia 36:381-8.

Maldonado, M.T., Hughes, M.P., Rue, E.L. \& Wells, M.L. 2002. The effect of Fe and Cu on growth and domoic acid production by Pseudo-nitzschia multiseries and Pseudo-

This article is protected by copyright. All rights reserved. 
nitzschia australis. Limnol. Oceanogr. 47:515-26.

Markina, Z. V. \& Aizdaicher, N.A. 2016. The effect of lowered salinity of sea water on the growth and photosynthetic pigment content in three strains of the microalgae Pseudonitzschia pungens (Grunow ex. P.T. Cleve) Hasle, 1993 (Bacillariophyta). Russ. J. Mar. Biol. 42:414-8.

Martin-Jézéquel, V., Calu, G., Candela, L., Amzil, Z., Jauffrais, T., Séchet, V. \& Weigel, P. 2015. Effects of organic and inorganic nitrogen on the growth and production of domoic acid by Pseudo-nitzschia multiseries and P. australis (Bacillariophyceae) in culture. Mar. Drugs. 13:7067-86.

Masmoudi, S., Nguyen-Deroche, N., Caruso, A., Ayadi, H., Morant-Manceau, A., Tremblin, G., Bertrand, M. et al. 2013. Cadmium, copper, sodium and zinc effects on diatoms: from heaven to hell - a review. Cryptogam. Algol. 34:185-225.

Mather, L., Macintosh, K., Kaczmarska, I., Klein, G. \& Martin, J.L. 2010. A checklist of diatom species reported (and presumed native) from Canadian coastal waters. Can. Tech. Rep. Fish. Aquat. Sci. 2881:1-78.

McCabe, R.M., Hickey, B.M., Kudela, R.M., Lefebvre, K.A., Adams, N.G., Bill, B.D., Gulland, F.M.D., Thomson, R.E., Chochlan, W.P. \& Trainer, V.L. 2016. An unprecedented coastwide toxic algal bloom linked to anomalous ocean conditions. Geophys. Res. Lett. 43:366-76.

Moschandreou, K.K., Baxevanis, A.D., Katikou, P., Papaefthimiou, D., Nikolaidis, G. \& Abatzopoulos, T.J. 2012. Inter-and intra-specific diversity of Pseudo-nitzschia (Bacillariophyceae) in the northeastern Mediterranean. Eur. J. Phycol. 47:321-39.

Nezan, E., Antoine, E., Fiant, L. \& Billard, C. 2006. Identification of Pseudo-nitzschia 
australis and $P$. multiseries in the Bay of Seine. Was there a relation to presence of domoic acid in king scallops in autumn 2004? Harmful Algae News 31:1-3.

Orive, E., Pérez-Aicua, L., David, H., García-Etxebarria, K., Laza-Martínez, A., Seoane, S. \& Miguel, I. 2013. The genus Pseudo-nitzschia (Bacillariophyceae) in a temperate estuary with description of two new species: Pseudo-nitzschia plurisecta sp. nov. and Pseudonitzschia abrensis sp. nov. J. Phycol. 49:1192-206.

Pan, Y., Bates, S.S. \& Cembella, A.D. 1998. Environmental stress and domoic acid production by Pseudo-nitzschia: a physiological perspective. Nat. Toxins. 6:127-35.

Pan, Y., Subba Raol, D. V, Mann, K.H., Brown, R.G. \& Pocklington, R. 1996. Effects of silicate limitation on production of domoic acid, a neurotoxin, by the diatom Pseudonitzschia m ultiseries. I . Batch culture studies. Mar. Ecol. Prog. Ser. 131:225-33.

Pancha, I., Chokshi, K., Maurya, R., Trivedi, K., Patidar, S.K., Ghosh, A. \& Mishra, S. 2015. Salinity induced oxidative stress enhanced biofuel production potential of microalgae Scenedesmus sp. CCNM 1077. Bioresour. Technol. 189:341-8.

Parkhill, J.P. \& Cembella, A.D. 1999. Effects of salinity, light and inorganic nitrogen on growth and toxigenicity of the marine dinoflagellate Alexandrium tamarense from northeastern Canada. J. Plankton Res. 21:939-55.

Pednekar, S.M., Bates, S.S., Kerkar, V. \& Prabhu Matondkar, S.G. 2018. Environmental factors affecting the distribution of Pseudo-nitzschia in two monsoonal estuaries of Western India and effects of salinity on growth and domoic acid production by $P$. pungens. Estuaries and Coasts. 41:1448-62.

Pulido, O.M. 2008. Domoic acid toxicologic pathology: a review. Mar. Drugs 6:180-219.

This article is protected by copyright. All rights reserved. 
Rhodes, L.L., Holland, P., Adamson, J., Selwood, A. \& McNabb, P. 2002. Mass culture of New Zealand isolates of Pseudo-nitzschia australis for production of a new isomer of domoic acid. Harmful Algae 125-7.

Schobert, B. 1974. The influence of water stress on the metabolism of diatoms I. Osmotic resistance and proline accumulation in Cyclotella meneghiniana. Zeitschrift für Pflanzenphysiologie. 74:106-20.

Schobert, B. 1977. The Influence of water stress on the metabolism of diatoms. Zeitschrift für Pflanzenphysiologie. 85:451-61.

Schreiber, U., Müller, J.F., Haugg, A. \& Gademann, R. 2002. New type of dual-channel PAM chlorophyll fluorometer for highly sensitive water toxicity biotests. Photosynth. Res. 74:317-30.

Stocker, T.F., Qin, D., Plattner, G.-K., Tignor, M.M.B., Allen, S.K., Boschung, J., Nauels, A. et al. 2013. Climate Change 2013: The Physical Science Basis. Contribution to the Fifth Assessment Report of the Intergovernmental Panel on Climate Change.

Tammilehto, A., Nielsen, T.G., Krock, B., Møller, E.F. \& Lundholm, N. 2015. Induction of domoic acid production in the toxic diatom Pseudo-nitzschia seriata by calanoid copepods. Aquat. Toxicol. 159:52-61.

Tasker, R.A. 2016. Domoic acid and other amnesic toxins: toxicological profile. In Gopalakrishnakone, P., Haddad, V., Kem, W. R., Tubaro, A. \& Kim, E. [Eds.] Marine and Freshwater Toxins. Springer S. Dordrecht, Netherlands, pp. 93-112.

Tatters, A.O., Fu, F. X. \& Hutchins, D.A. 2012. High CO2 and silicate limitation synergistically increase the toxicity of Pseudo-nitzschia fraudulenta. PLoS ONE 7:e32116.

This article is protected by copyright. All rights reserved. 
Teng, S.T., Tan, S.N., Lim, H.C., Dao, V.H., Bates, S.S. \& Leaw, C.P. 2016. High diversity of Pseudo-nitzschia along the northern coast of Sarawak (Malaysian Borneo), with descriptions of P. bipertita sp. nov. and P. limii sp. nov. (Bacillariophyceae). J. Phycol. 52:973-89.

Tesson, S.V.M., Montresor, M., Procaccini, G. \& Kooistra, W.H.C.F. 2014. Temporal changes in population structure of a marine planktonic diatom. PLOS ONE 9:e114984.

Thessen, A.E., Bowers, H.A. \& Stoecker, D.K. 2009. Intra-and interspecies differences in growth and toxicity of Pseudo-nitzschia while using different nitrogen sources. Harmful Algae 8:792-810.

Thessen, A.E., Dortch, Q., Parsons, M.L. \& Morrison, W. 2005. Effect of salinity on Pseudonitzschia species (Bacillariophyceae) growth and distribution. J. Phycol. 41:21-9.

Thessen, A.E. \& Stoecker, D.K. 2008. Distribution, abundance and domoic acid analysis of the toxic diatom genus Pseudo-nitzschia from the Chesapeake Bay. Estuaries and Coasts. 31:664-72.

Trainer, V.L., Adams, N.G., Bill, B.D., Stehr, C.M., Wekell, J.C., Moeller, P., Busman, M. \& Woodruff, D. 2000. Domoic acid production near California coastal upwelling zones, June 1998. Limnol. Oceanogr. 45:1818-33.

Trainer, V.L., Bates, S.S., Lundholm, N., Thessen, A.E., Cochlan, W.P., Adams, N.G. \& Trick, C.G. 2012. Pseudo-nitzschia physiological ecology, phylogeny, toxicity, monitoring and impacts on ecosystem health. Harmful Algae 14:271-300.

Trainer, V.L., Hickey, B.M., Lessard, E.J., Cochlan, W.P., Trick, C.G., Wells, M.L., MacFadyen, A. \& Moore, S.K. 2009. Variability of Pseudo-nitzschia and domoic acid in the Juan de Fuca eddy region and its adjacent shelves. Limnol. Oceanogr. 54:289-308.

This article is protected by copyright. All rights reserved. 
Van Meerssche, E. \& Pinckney, J.L. 2017. The influence of salinity in the domoic acid effect on estuarine phytoplankton communities. Harmful Algae 69:65-74.

Visciano, P., Schirone, M., Berti, M., Milandri, A., Tofalo, R. \& Suzzi, G. 2016. Marine biotoxins: occurrence, toxicity, regulatory limits and reference methods. Front. Microbiol. 7:1051.

Wells, M.L., Trainer, V.L., Smayda, T.J., Karlson, B.S.O., Trick, C.G., Kudela, R.M., Ishikawa, A. et al. 2015. Harmful algal blooms and climate change: Learning from the past and present to forecast the future. Harmful Algae 49:68-93.

Zapata, M., Rodríguez, F., Fraga, S., Barra, L. \& Ruggiero, M.V. 2011. Chlorophyll $c$ pigment patterns in 18 species (51 strains) of the genus Pseudo-nitzschia (bacillariophyceae). J. Phycol. 47:1274-80.

This article is protected by copyright. All rights reserved. 
Figure 1: Percentage mortality and growth rate $(\mu)$ in strains IFR-PAU-16.1 and IFRPAU-16.2 exposed to a broad range of salinities: 10, 20, 30, 40 and 35 (control). Data are means $\pm \mathrm{SD}, \mathrm{n}=3$. ( $\mu$ calculated between day 1 and 3 for salinities 30 and 35 , and between day 0 and 1 for salinities 10,20 and 40). * Significant difference between cultures grown at salinities 10 and 20 compared with the control at 35 (for strain IFR-PAU-16.1: $\mathrm{p}=3 \times 10^{-6}$, and $p=6 \times 10^{-6}$, respectively and for strain IFR-PAU-16.2: $p=3 \times 10^{-7}$, and $p=2 \times 10^{-6}$, respectively).

Figure 2: Effect of different salinity conditions: 40, 35, 30, 20 and 10 on cell densities for in strains IFR-PAU-16.1 (A) and IFR-PAU-16.2 (B). Time 0 refers to the cell transfer to the new salinity treatment media. Data are means $\pm \mathrm{SD}, \mathrm{n}=3$.

Figure 3: Variation in the effective quantum yield $Q Y=F_{v} / F_{m}$ in strains IFR-PAU16.1 (A) and IFR-PAU-16.2 (B) in response to salinity conditions 10, 20, 30, 35 and 40. Data are means $\pm \mathrm{SD}, \mathrm{n}=3$. * Significant difference between cultures at salinities 10 and 20 compared to the control at salinity 35 (for strain IFR-PAU-16.1: $\mathrm{p}=9 \times 10^{-25}$, and $\mathrm{p}=9 \times 10^{-23}$, respectively and for strain IFR-PAU-16.2: $\mathrm{p}=4 \times 10^{-26}$, and $\mathrm{p}=6 \times 10^{-11}$, respectively).

Figure 4: Particulate, dissolved and total domoic acid concentrations in strains IFRPAU-16.1 (A, C, E) and IFR-PAU-16.2 (B, D, F) subjected to different salinity conditions: 40, 35, 30, 20 and 10. Data are means $\pm \mathrm{SD}, \mathrm{n}=3$. 
Table S1: Individual data point of the percentage of mortality and growth rate $(\mu)$ in strains IFR-PAU-16.1 and IFR-PAU-16.2 exposed to a broad range of salinities: 10, 20, 30, 40 and 35 (control). Data are means $\pm S D, n=3$. ( $\mu$ calculated between day 1 and 3 for salinities 30 and 35, and between day 0 and 1 for salinities 10, 20 and 40).

Figure S1: Semi-log plots of cell counts measured for the two strains IFR-PAU-16.1 and Ifr-PAU-16.2 grown at salinities 35 and 30.

This article is protected by copyright. All rights reserved. 


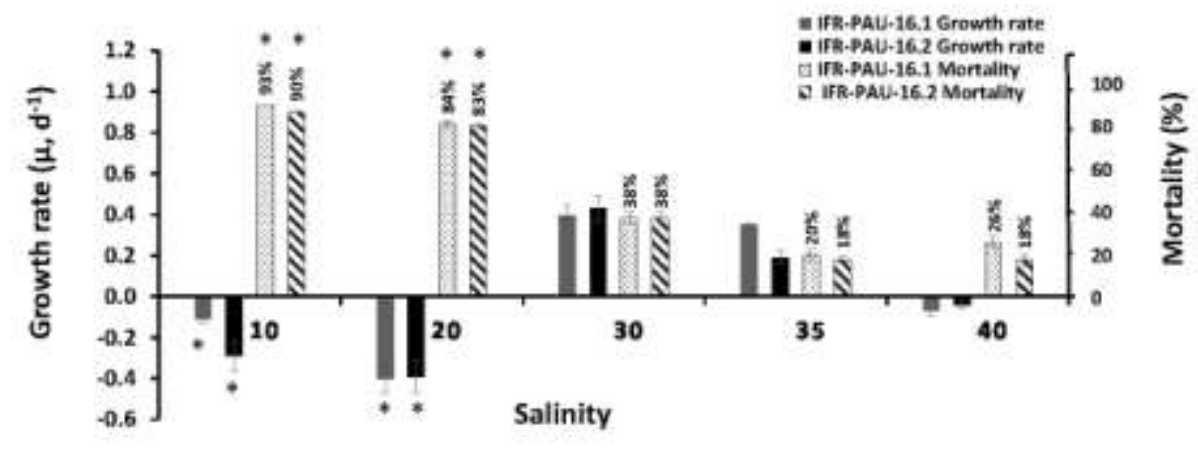

This article is protected by copyright. All rights reserved. 

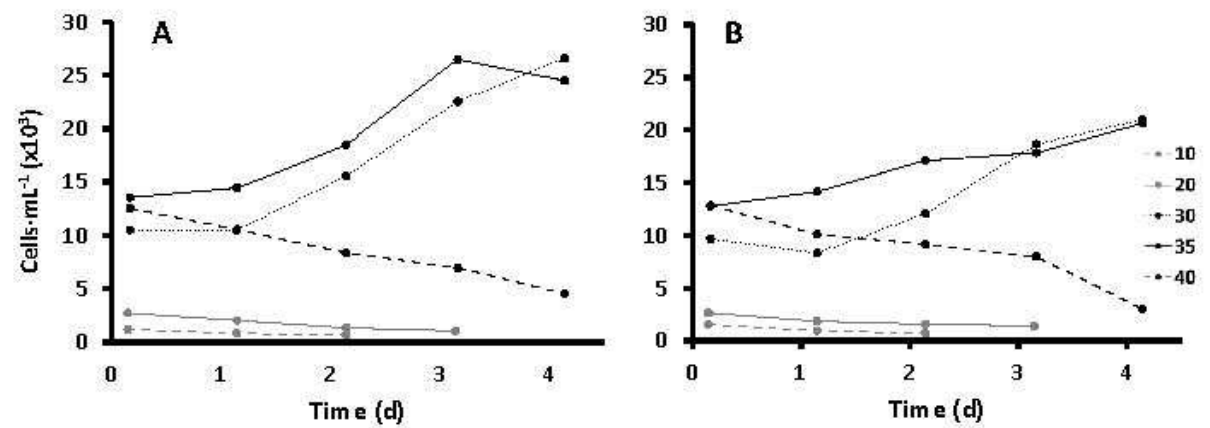

This article is protected by copyright. All rights reserved. 

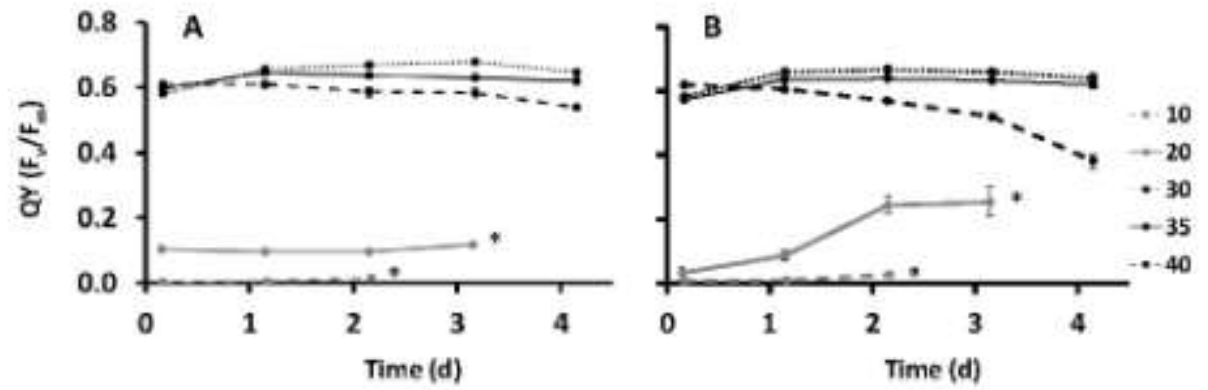

This article is protected by copyright. All rights reserved. 

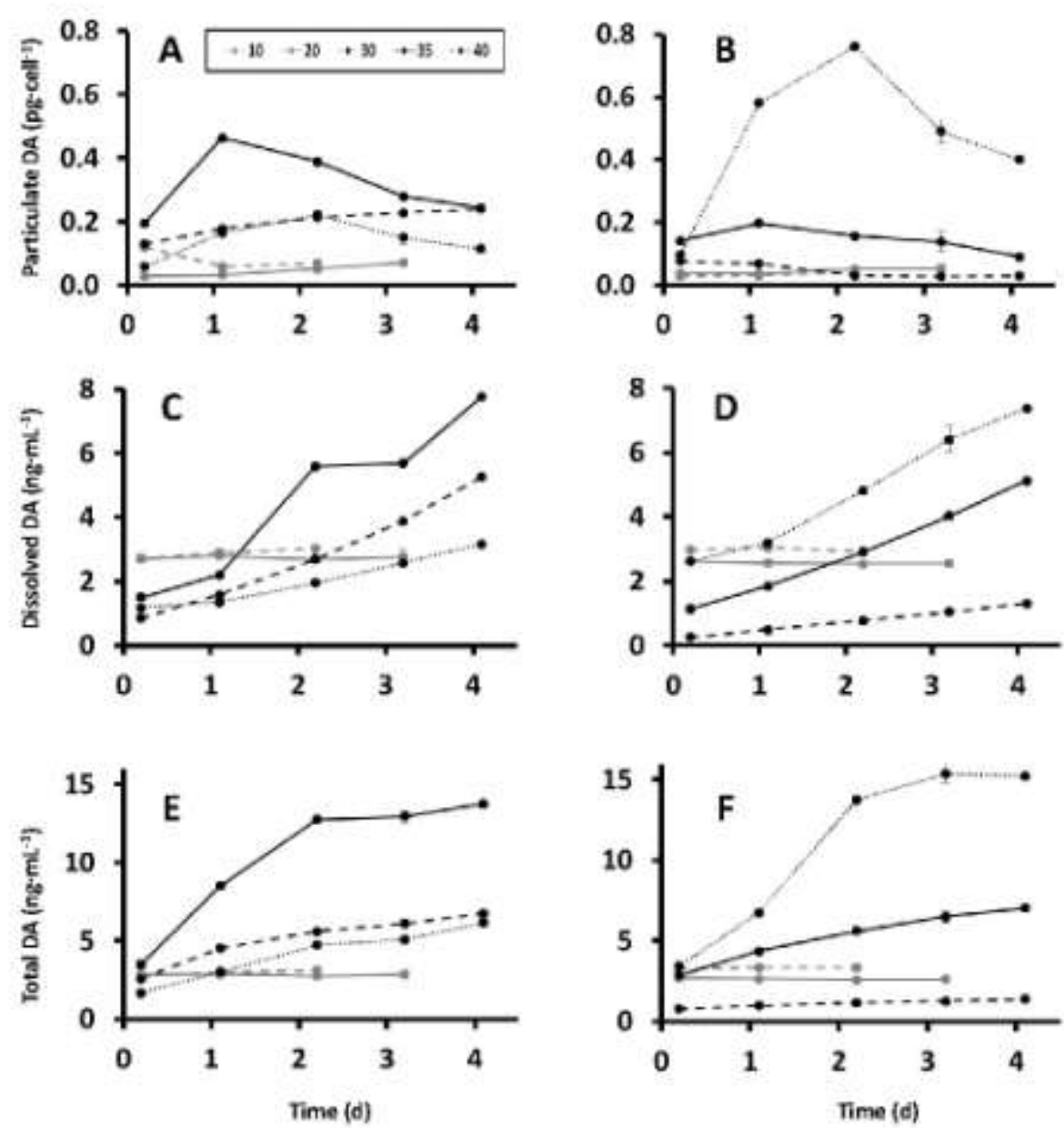

This article is protected by copyright. All rights reserved. 